\title{
AUTHORITY FOR MINERAL AND COAL MANAGEMENT IN THE ERA OF REGIONAL AUTONOMY AND ITS IMPLICATIONS IN VIEW OF ARTICLE 33 PARAGRAPH (3) OF THE 1945 CONSTITUTION
}

\author{
Tri Hayati ${ }^{*}$ \\ * Senior lecturer at Faculty of Law - University of Indonesia.
}

\section{Article Info}

Received : 26 May 2014 | Received in revised form : 7 August 2014 | Accepted : 16 October 2014

Corresponding author's e-mail : tri_hariri@yahoo.com

\begin{abstract}
The adoption of Law Number 22 Year 1999 led to the expansion of regional governments'autonomy, applying autonomy in the broadest sense of the word, by focusing merely on 'decentralization', while disregarding the principle of de-concentration. Governmental affairs submitted based on decentralization refer to authority by attribution, whereas de-concentration refers to authority by delegation. Prior to the reform era, the management of mining was based on Law Number 11 Year 1967, whereby the basis of management authority was the classification of excavated materials namely category $a$, category $b$, and category $c$. Subsequently, with the implementation of the reform era, Law Number 11 Year 1967 was negated by the adoption of Government Regulation Number 75 Year 2001, granting mining management authority to the Minister, Governor, Regent or Mayor concerned in accordance with their authority respectively. As a result of the above, the concept as provided for in Law Number 11 Year 1967 became inapplicable. This continued to be the case up to the adoption of Law Number 4 Year 2009 concerning Mineral and Coal Mining, which in principle adopts the concept which has been adjusted to the concept of granting autonomy to the regional government as set forth in Law Number 22 Year 1999.
\end{abstract}

Keywords : Regional Governance, Reform, Decentralization, State Control

\begin{abstract}
Abstrak
Berlakukannya Undang-undang Nomor 22 Tahun 1999, membawa dampak pembesaran otonomi pemerintah daerah, terutama pada Kabupaten dan Kota, dengan diterapkannya otonomi seluasluasnya, dimana asas yang diterapkan hanya "desentralisasi" semata, tanpa penerapan asas dekonsentrasi. Urusan pemerintahan yang diserahkan berdasarkan desentralisasi merujuk pada kewenangan atribusian, sedangkan dekonsentrasi merujuk pada kewenangan delegasian. Sebelum era reformasi pengelolaan pertambangan didasarkan pada Undang-undang Nomor 11 Tahun 1967, dimana kewenangan pengelolaan didasarkan pada penggolongan bahan galian golongana, golongan b, dan golongan c. Kemudian setelah berlangsungnya era reformasi, Undangundang Nomor 11 Tahun 1967 ternegasikan dengan dibentuknya Peraturan Pemerintah Nomor 75 Tahun 2001, yang memberikan kewenangan pengelolaan pertambangan kepada Menteri, Gubernur, Bupati atau Walikota sesuai kewenangan masing-masing. Dengan demikian konsep sebagaimana diatur Undang-undang Nomor 11 Tahun 1967 menjadi tidak dapat diterapkan. Hal ini berlangsung sampai terbitnya Undang-undang Nomor 4 Tahun 2009 tentang Pertambangan Mineral dan Batubara, yang pada dasarnya menganut konsep yang disesuaikan dengan konsep pemberian otonomi kepada pemerintah daerah sebagaimana diatur Undang-undang Nomor 22 Tahun 1999.
\end{abstract}

Kata Kunci : Pemerintahan Daerah, Reformasi, Desentralisasi, Penguasaan Negara 


\section{Introduction}

In the history of mining management since the era of the Dutch Indies up to the present time there have been many ups and downs. The Indische Mijnwet of 1899, which marked the beginning of mining management, was based on the principle of discrimination by granting priority right to investors from the Dutch Indies group while treating indigenous Indonesians (pribumi) as number two priority. Such treatment was certainly detrimental to the Indonesian nation. The situation was further aggravated by granting extensive rights to concession holders, including control of natural resources. Such conditions prevailed for a rather long period of time, up until the adoption of the mining law as the legislative product of the Indonesian nation.

Following the proclamation of independence, the State of the Republic of Indonesia started to introduce measures for the management of mining in order to bring them in line with the mandate of Article 33 paragraph (3) of the 1945 Constitution of the State of the Republic of Indonesia. In 1960, Law Number 37 Year 1960 was adopted, setting forth the policy of closing the mining management sector to foreign investors. The said law completely prevented foreign investors from investing in Indonesia, brining an unfavorable impact on state finances which became depleted quite significantly. The Government eventually introduced new measures in 1967 by adopting Law Number 1 Year 1967 concerning Foreign Capital Investment. The newly introduced policy reopened the opportunity to foreign investors to invest in Indonesia. In anticipation of the said policy, policy in the mining sector was reformed by adopting Law Number 11 Year 1967 concerning the Basic Mining Provisions, re-opening the opportunity to investors to engage in mining activities. Law Number 11 Year 1967 was successful in attracting foreign investors.

The concept adopted in Law Number 11 Year 1967 basically puts attribution mining management authority in the hands of the Central Government (centralistic). Authority in mining management is based on the classification of excavated materials into three categories, namely category a, category b and category $\mathrm{c}$ as provided for under Government Regulation Number 37 Year 1986. The centralistic principle in mining management is obviously in line with the concept of control by the state (penguasaan negara) as intended in Article 33 of the 1945 Constitution of the State of the Republic of Indonesia. With the exception of authority in the management of category c excavated materials considered as locality, granting the same to the Regional Government. Mining right was granted to business actors in the form of Mining Concessions, Contracts of Work and Coal Management Work Agreements (PKP2B).

Over time, parallel to the development of the Regional Autonomy Reform Era, it was felt that the centralistic concept of Law Number 11 Year 1967 was no longer suitable. The adoption of Law Number 22 Year 1999 led to various fundamental changes in the administration of governance in Indonesia. Mining management, too, was subject to fundamental changes in view of mining management authority. The concept adopted by Law Number 22 Year 1999 provides extremely broad authority to the Regency and Municipality Regional Governments. Such decentralization concept stands in stark contrast with the centralization concept adopted by Law Number 11 Year 1967, creating dualism in mineral and coal mining management authority in Indonesia. This eventually led to various issues on the site, particularly at the level of the Regency and Municipality regional governments, as they felt that they 
had obtained broad regional autonomy, including in the area of mining affairs. Other consequences included the proliferation of illegal mining operating under cover as people's mining, overlap in licensing within the mining sector as well as across other sectors. There was also a rather long-lasting legal uncertainty prevailing in mining management until the issuance of Law Number 4 Year 2009 concerning Mineral and Coal Mining. It is expected that the adoption of Law Number 4 Year 2009 will bring a positive impact on mining management in Indonesia. Law Number 4 Year 2009 has adopted the decentralization principle, hence it is synchronized with the principle of regional autonomy adopted by Law Number 22 Year 1999, as replaced by Law Number 32 Year 2004 concerning Regional Governance. The question is whether Law Number 4 Year 2009 has adopted the mandate articulated in Article 33 paragraph (3) of the 1945 Constitution?

In writing this article the normative juridical methodology is applied, examining various norms in the regulation related to mining management in Indonesia. However, the regulations examined are considered from the aspect of regional governance reform era, namely by taking into account the regulation prior to the reform era based on Law Number 11 Year 1967 and in the post-reform era, namely based on Government Regulation Number 75 Year 2001 and Law Number 4 Year 2009. Accordingly, the data used in this study are secondary data consisting of primary, secondary and tertiary legal materials.

\section{The Concept of Control by the State (Penguasaan Negara) Related to Regional Autonomy}

The concept of control by the state (penguasaan negara) as mandated in the 1945 Constitution of the State of the Republic of Indonesia needs to be applied and serve as the spirit of various laws and regulations concerning natural resources. Article 33 as the basis of the State's Right to Control (Hak Penguasaan Negara) lays down the bases for the economic system and economic activities envisaged in the State of the Republic of Indonesia. In Article 33 paragraph (3) of the 1945 Constitution it is stated that the land, water and natural resources contained therein shall be controlled by the State ${ }^{1}$ and shall be used for the greatest prosperity of the people. It is therefore expressly stated in the 1945 Constitution that excavated materials as natural resources contained in the land are controlled by the State and not by the Government, whereby it can be implied that the Government also means the Regional Government. It is therefore obvious that "hak penguasaan" (the right to control) (Authority Right) with regards to excavated materials is in the hands of the State, rather than the Government. At the same time, "hak kepemilikan" (proprietary

\footnotetext{
${ }^{1}$ Following are several interpretations of control by the State ('dikuasai oleh Negara'): (1) Mohammad Hatta: control by the State does not mean that the State itself acts as an entrepreneur, business person or ondernemer. It is more appropriate to say that control by the State is in the form of making regulations for the purpose of ensuring the uninterrupted flow of economy, regulations which at the same time prevent exploitation of the weak by those who possess capital, (2) Muhammad Yamin: the definition control by the State includes regulating and/or administering particularly with the aim of improving and enhancing production by giving priority to cooperatives, (3) The Finance and Economics Committee (Panitya Keuangan dan Perekonomian) formed by the BPUPKI chaired by Mohammad Hatta: the definition of control by the State implies that the Government must act as supervisor and regulator guided by the people's safety. The larger a company, and the more people depend on it for their livelihood, there is a need for the Government's participation. The land must be under State power. And large mining companies are to be operated as State enterprises. (Abrar Saleng, Op.Cit., p. 17-18).
} 
right) (Mineral Right) of excavated materials is in the hands of the Indonesian Nation (the entire people). Furthermore, "hak pengelolaan" (management right) (mining right) is in the hands of the Government, and only then followed by "hak pengusahaan" (the right to operate) (economic right) which is in the hands of business actors. ${ }^{2}$

Accordingly, seen from the philosophical point of view, control over natural resources including minerals and coal has been granted by the people to the State, to be managed by the government for the prosperity of the people to the greatest possible extent. The foregoing implies that authority by attribution to manage natural resources is in the hands of the Central Government. Article 33 of the 1945 Constitution grants the mandate to the State to control natural resources for the prosperity of the entire people. The said article can also be interpreted as the basis for appropriate management, and not only control, by the State, in this case implemented by the Government. Natural resources should be managed in a wise and just manner, not focusing exclusively on the growth of investment and state foreign exchange earnings. There is a need for clear and explicit regulation on a continuous basis related to transparency, participation and accountability in management moving towards good governance and the democratization of mining management as well as good mining practices.

J.J Rousseau states that the power of the State as a social entity or organization is derived from social contract, essentially to protect and defend common property, private property and every individual. State power is not unlimited, as there is law (leges imperii) setting the boundaries. According to Yudha B. Ardiwisastra, leges imperii is the fundamental law which sets forth provisions concerning the parties to which such power is granted and the boundaries for the implementation thereof. In line with such limited power, the power over natural resources is theoretically derived from the people, known as the Nation's Right (Hak Bangsa). In such context, the State is viewed as a territory with character (Character State) as a sovereign legal society institution hence it has the capacity to act within and outside the State. In this particular case, only the Central Government has the capacity to act both within as well outside the State, therefore it is granted authority and power to regulate, manage and maintain the use of all natural resource potentials which exist in the territory of the State of the Republic of Indonesia. ${ }^{3}$ Accordingly, there is a need to realign the condition of the currently existing regulations related to authority in the management of mining with the mandate of Article 33 of the 1945 Constitution, whereby it is the Central Government that should act as the institution vested with the authority to manage mining related affairs. With the exception of mining activities of local nature, however, which should be given to the regional government concerned.

The right to control mining excavated materials in Indonesia is implemented in the form of licesing. All natural resources related business activities, which constitute acts undertaken by the State, the government and implementing agencies, must be based on applicable law. ${ }^{4}$ The highest law applicable to the management of natural resources is Article 33 paragraph (3) of the 1945 Constitution of the State of the

\footnotetext{
${ }^{2}$ Tri Hayati, Perizinan Pertambangan di Era Reformasi Pemerintahan Daerah, Studi tentang Perizinan Pertambangan Timah di Pulau Bangka (Mining Licensing in the Era of Regional Governance Reform, A Study of Licensing of Tin Mining on the Island of Bangka), print 1. Jakarta : Badan Penerbit Fakultas Hukum Universitas Indonesia (Faculty of Law, Universitas Indonesia, Press), 2012, h. 62-63.

${ }^{3}$ Abrar Saleng, Hukum Pertambangan (Mining Law), second print. (Jogjakarta : UII Press, 2007), p.8.

${ }^{4}$ Republic of Indonesia, Undang-Undang Dasar 1945 (1945 Constitution), Article 1 paragraph (3) : Indonesia is a State Based on Law (Negara Hukum).
} 
Republic of Indonesia. ${ }^{5}$ This is further articulated in Law Number 11 Year 1967, stating as follows:

"Semua excavated materials yang terdapat dalam wilayah hukum pertambangan Indonesia yang merupakan endapan - endapan alam sebagai Karunia Tuhan Yang Maha Esa adalah kekayaan nasional bangsa Indonesia dan oleh karenanya dikuasai oleh Negara dan dipergunakan untuk sebesar-besar kemakmuran rakyat". ${ }^{6}$ [Unofficial translation: "All excavated materials within the mining legal jurisdiction of Indonesia which are natural sediments as the Blessings of The One Almighty God are the national riches of the Indonesian nation and are therefore controlled by the State and are used for the greatest possible prosperity of the people."]

Furthermore, in Article 4 paragraph (1) it is provided that the implementation of the State's control and the regulation of category a and category b excavated materials mining business are implemented by the Minister. This is clear indication that the attribution authority in mining management is vested in the Central Government, except for category c excavated materials.

State control over natural resources under Law Number 11 Year 1967 vested with the Government is further manifested in the form of "Kuasa Pertambangan" (KP) (Mining Concession). Mining concession is authority granted to Entities or Individuals to undertake mining business activities. ${ }^{7}$ Such authority is the right and power granted under law to entities/individuals to engage in the mining sector. The official who has the capacity to grant such authority to entities/individuals is the Minister, set out in a Decree for Granting Mining Concession, as a form of "public license".

Mining Concession for category a and category b excavated materials, by virtue of Law Number 11 Year 1967 is basically the Government's authority. However, with the adoption of Law Number 22 Year 1999 concerning Regional Governance, the authority to issue mining concessions has been interpreted as being the authority of the autonomous region concerned, particularly Regency and Municipality enjoying regional autonomy to the broadest possible extent. In order to accommodate changes concerning regional autonomy as intended in Law Number 22 Year 1999, the Ministry of Energy and Mineral Resources issued Government Regulation Number 75 Year 2001 concerning the Second Amendment of Government Regulation Number 32 Year 1969 concerning the Implementation of Law Number 11 Year 1967, which grants authority by attribution to the Regency and Municipality Regional Government.

Government Regulation Number 75 Year 2001 states that Mining Concession is issued by the Regent/Mayor/Governor or the Minister in accordance with their authority respectively. ${ }^{8}$ Accordingly, the underlying paradigm of regulation is accommodating

${ }^{5}$ The Republic of Indonesia, Undang-Undang Dasar 1945 (1945 Constitution), Article 33 paragraph (2) and paragraph (3) : (2) Production branches which are important for the state and which affect the livelihood of the public shall be controlled by the state. (3) Land and water and the natural resources contained therein shall be controlled by the state and shall be used for the greatest prosperity of the people. [unofficial translation]

${ }^{6}$ Indonesia, Undang-Undang Number 11 Year 1967 tentang Ketentuan-Ketentuan Pokok Pertambangan (Law Number 11 Year 1967 concerning Basic Mining Provisions), State Gazette Year 1967 Number 22, Supplement to State Gazette Number 2831, Article 1.

${ }^{7}$ Undang Undang Number 11 Year 1967 tentang Ketentuan Pokok-Pokok Pertambangan (Law Number 11 Year 1967 concerning Basic Mining Provisions), Article 2 sub-article i.

${ }^{8} \mathrm{KP}$ can be granted by: (a) Regent/Mayor if the WKP is located in the territory of the Regency/Municipality concerned, and/or in sea territory up to 4 nautical miles; (b) Governor if the KP Area is located in several Regencies/Municipalities and if there is no cooperation between the Regencies/Municipalities 
the concept of regional autonomy in the management of mining, by vesting the management of mining with the regional government. It has created asynchrony with Law Number 11 Year 1967, which basically adopts the centralistic concept, ultimately leading to dualism of authority in mining management in Indonesia under Law Number 11 Year 1967 on the one hand, and Government Regulation Number 75 Year 2001 on the other. In the legal system prevailing in Indonesia, the policy of autonomous regions is only supposed to further outline the policy formulated by the Government. Therefore, if an asynchrony in policy occurs in Government policy, or between the Government and Autonomous Regions, policy at the autonomous region should be guided by the policy at the Government level. There is an absolute need for synchronization in the context of upholding the Unitary State of the Republic of Indonesia. At the same time, any Government Regulation implementing regulation of Law must be synchronized with the Law mandating it. The above described dualism has been going on ever since the adoption of Law Number 4 Year 2009.

With the adoption of Law Number 4 Tahun 2009 concerning Mineral and Coal Mining in December, the paradigm of regional autonomy as set out in Law Number 22 Year 1999 jo. Law Number 32 Year 2004 jo. Government Regulation Number 75 Year 2001, was accommodated. Law Number 4 Year 2009 grants authority for mineral and coal management to the Government, Province, Regency and Municipality in accordance with their authority respectively. Accordingly, there is no longer classification of excavated materials in mining, whereby authority by attribution with regards to strategic and vital excavated materials is exclusively vested in the Central Government. The Regional Government deals only with excavated materials of local nature, namely category c excavated materials. The centralistic paradigm which maintains the concept of State Control referring to the "character state" is no longer present.

The concept of control by the state under Law Number 4 Year 2009 sets out that minerals and coal as non-renewable natural resources are natural wealth which are controlled by the state for the greatest possible prosperity of the people. Such control by the state of minerals and coal is administered by the Government and/or the regional government ${ }^{9}$ concerned. For national strategic purposes the Government, with the consent of the House of Representatives (DPR), stipulated State Reserve Areas (wilayah pencadangan negara or WPN) for minerals and coal. This is quite different from Law Number 11 Year 1967, whereby control over excavated materials is basically administered by the Government, in this case being implemented by the Ministry of Energy and Mineral Resources.

Accordingly, the concept of control by the State as mandated in Article 33 of the 1945 Constitution has significantly shifted from Law Number 11 Year 1967 towards Law Number 4 Year 2009. Vesting the right of control with the Government is determined based on the philosophy of Article 33 UUD 1945 with the understanding that the "State" is the holder of sovereignty which can act within and outside. In this case, the organ which has the ability to act within and outside is the "Central Government, which does not include the "Regional Government" (which has the authority to act

concerned or between the Muncipalities/Regencies and the Province concerned and/or in sea territory located between 4 to 12 nautical miles; (c) Minister if the KP Area is located in several Provinces and there is no cooperation between the Provinces concerned and/or in sea territory located beyond 12 nautical miles. (Article 1 paragraph (2) Government Regulation Number 32 Year 1969 concerning the Implementation of Law Number 11 Year 1967 concerning Basic Mining Provisions. State Gazette of the Republic of Indonesia Year 1967 Number 22, Supplement to State Gazette Number 2831).

${ }^{9}$ The Republic of Indonesia, Law Number 4 Year 2009, Article 4 paragraph (1) and paragraph (2). 
only internally, it does not have the sovereignty to take outward action). Accordingly, the actual concept of control by the state under Article 33 of the 1945 Constitution is being vested in the State as the holder of sovereignty and an organ which has the capacity to act inside and outside representing the State. Accordingly, the concept of mining management as adapted to the granting of autonomy to the Regional Governments, needs to be re-examined in order to adjust it to the "concept of control by the state" by virtue of Article 33 paragraph (3) of the 1945 Constitution. It can be stated that with the adoption of Law Number 4 Year 2009 the concept of control by the state as mandated in Article 33 paragraph (3) has gone through degradation.

\section{III.The Right to Control by the State and the Implications Thereof on Licensing}

Viewed from the aspect of public interest theory as stated by Anthony I. Ogus, there are two types of objects implying public interest ${ }^{10}$, namely public interest in the form of public goods and public ownership. Public Goods mean that certain objects have the nature of public interest and they do not contain any proprietary rights whatsoever by anybody. It is therefore the Government's responsibility to control the use thereof ensuring that they can be accessed by the public in an equitable manner, through various licensing in the form of vergunning (Public Licenses). At the same time, public ownership ${ }^{11}$ implies the understanding that a certain object has a public interest character and such object is the property of the all the people. Therefore, the utilization thereof must be able to bring benefit and welfare to the people as a whole in an equitable way. Accordingly, the use and utilization of such goods must be in principle implemented by the Government itself. If the Government is not prepared or if it is unable to implement it by itself, it can be submitted to third parties while remaining under the control of the Government through various licensing in the form of concessions (concessie). It is granted in the form of concession (concessie) because the Licenses issued are bound have an impact in the form of broad authority and various related rights and obligations for the party receiving such concession licenses. It is therefore necessary to ensure that licenses issued for the use of public ownership are accompanied with an agreement limiting the rights and obligations of the party granted such concession license.

According to the theory of licensing as adopted by The Netherlands, licensing related to public ownership can be granted in the form of concession (concessie) accompanied by the limitation of various rights and obligations of the concession holder as set out in an agreement. The issuance of concession (concessie) must still be based on prior approval of the Minister in his capacity representing the State's right to control. In principle, the party receiving concession takes over a portion of the mission of bestuurszorg (governmental affairs) of state administration in a modern welfare state. Therefore, the utilization of a certain object which has the nature of public interest must be basically controlled by the government in order to ensure that there is no monopoly over such object, hence it can provide benefit and welfare to the people as a whole.

Under Law Number 4 Year 2009, in view of the adoption of the concept of State control over natural resources, it is stated that the State's right to control is exercised

\footnotetext{
${ }^{10}$ Anthony I. Ogus, Regulations Legal Form and Economic Theory. Portland, Oregon : Hart Publishing, 2004, p. 227.

${ }^{11}$ Anthony I. Ogus, Ibid., p. 271.
} 
by the Government and the Regional Government concerned. Accordingly, authority by attribution is vested not only in the Central Government, but also in the Regional Government, in accordance with their authority respectively. It implies that there is an asynchrony vis-à-vis Article 33 of the 1945 Constitution of the State of the Republic of Indonesia which states that control over natural resources is in the hands of the State, which means that it is in the hands of the Central Government alone. Only locality needs can be derived to the Regional Government. It is stated in Article 33 of the 1945 Constitution of the State of the Republic of Indonesia that control over natural resources is in the hands of the State, which means that it is implemented by the Government (in the context of character state), hence it cannot be derived to the Regional Government (only locality needs can be derived).

Law Number 4 Year 2009 concerning Mineral and Coal Mining adopts several forms of licensing, namely as follows:

1) Izin Usaha Pertambangan IUP) Mining Business License) is a business license to conduct mining, issued by the Minister, Governor, Regency in accordance with their authority respectively Article 1 sub-article 7), including the following:

a) Exploration IUP is a business license issued for engaging in the stage of general investigation, exploration and feasibility study related activities Article 1 sub-article 8);

b) Production Operation IUP is business license issued upon completion of the Exploration IUP for engaging in production operation activities Article 1 subarticle 9). Production Operation IUP consists of construction, development, processing and refinery activities, as well as transportation and sales.

2) People's Mining License $I P R$ ) is a license for conducting mining in people's mining territory with a limited area and investment, issued by the Minister, Governor, Regent in accordance with their authority respectively Article 1 sub-article 10). The Regent/Mayor concerned issues IPR especially to local residents, either to individuals for a maximum of 1 hectares or to community groups for a maximum of 5 hectares and/or cooperatives for a maximum of 10 hectares. This can be delegated to the district head camat) in accordance with applicable laws and regulations.

3) Special Mining Business License $I U P K$ ) is a license to conduct mining business within the special mining business license territory WIUPK: Article 1 sub-article 11). Special mining business license territory is territory granted to holders of IUPK Article 1 sub-article 35).

\section{IUPK consists of two stages:}

Exploration stage $\boldsymbol{I U P K}$ is a license issued for engaging in the stage of general investigation, exploration and feasibility study related acctivities in the special mining business license territory (Article 1 sub-article 12).

Production Operation stage IUPK is a license issued upon completion of the Exploration $I U P K$ for engaging in the production operation stage in the special mining business license territory (Article 1 sub-article 13).

The licensing concept adopted in Law Number 4 Year 2009, according to the theory of Anthony I. Ogus should be in fact part of the Public Ownership category, as it belongs to the category as intended in Article 33 paragraph (3) of the 1945 Constitution. The 
land, water and natural resources contained in Indonesian ground are the property of the entire Indonesian people hence the use thereof must be aimed at creating welfare to the Indonesian people as a whole. Accordingly, in the context of their management, every person/entity intending to engage in mining activities must obtain concession license from the competent Government Official. The currently applicable form of Mining Business License (IUP) sets out a kind of an agreement which limits the rights and obligations of the IUP holder concerned. Even though from the juridical formal point of view the nomenclature adopted in Law Number 4 Year 2009 is LICENSE $(I Z I N)$, from the material viewpoint the IUP belongs to the Concession license category.

\section{Authority of Public Officials in the Context of State Administration Law}

In the context of State Administration Law, prior to implementing public governmental functions (bestuurszorg) a public official is first of all granted valid authority based on prevailing laws and regulations. It is the consequence of the concept of Welfare State based on law adopted by Indonesian, whereby all actions undertaken by public officials must be based on authority granted under laws and regulations as a basis for their legality. ${ }^{12}$ According to Carol Harlow and Richard Rowling, by adopting the concept of welfare state in Indonesia, increasingly broad authority is granted to public officials facilitated by State Administration Law. ${ }^{13}$ The prevailing law, particularly State Administration Law, is a legal matrix ${ }^{14}$ both for the central as well as the regional governments. In principle, the legal matrix creates the ground for justifying the actions and activities conducted by State administration officials.

In general, authority is the power to undertake public law action, manifested as the right to run governmental affairs (in the narrow sense of the word), and the right to influence in a concrete manner decisions to be made by government institutions. ${ }^{15}$ According to Peter Leyland, public authority has two main characteristics, namely: (a) every decision made by a government official has binding force on all members of the community and (b) every decision made by a government official has a public function, in the sense of serving the public. ${ }^{16}$ In the view of Prayudi Atmosudirdjo, authority consisting of several authorities, is power over a certain group of people or authority over a certain government entity. Authority includes several authorities (rechtsbevoegdheden). Authority is the power to undertake certain public law acts, ${ }^{17}$ such as for instance the authority of an official to sign a license on behalf of the Minister, while authority remains with the Minister concerned (delegation of authority).

It is considered that the Government has authority, and it is therefore entitled to issue orders, undertake certain acts and make laws and regulations. Authority consisting of several authorities is formal power, namely power originating from legislative power. Thus, authority is formal power deriving from public law, serving as a basis for

\footnotetext{
${ }^{12}$ The Republic of Indonesia, 1945 Constitution, Article 1 paragraph (3).

${ }^{13}$ Carol Harlow and Richard Rowling, Law and Administration. London : Butterwoths, 1997, p. 67.b.

${ }^{14}$ Safri Nugraha et al., Hukum Administrasi Negara (State Administration Law), Jakarta : Badan Penerbit Fakultas Hukum Universitas Indonesia (Faculty of Law, Universitas Indonesia Press), 2005, p. 61.

${ }^{15}$ Safri Nugraha et al., Hukum Administrasi Negara (State Administration Law), second edition. Jakarta : Center For Law and Good Governance Studies, FHUI, 2007, p. 29-30.

${ }^{16}$ Peter Leyland and Terry Woods, Administrative Law, third edition. London : Blackstone Press Limited, 1999, p.157.

${ }^{17}$ Prayudi Atmosudridjo, Op.Cit., p. 78.
} 
undertaking acts in accordance with the provisions of public law for the government taking legal acts. ${ }^{18}$

There must be a legal authority basis for every act undertaken by state administration officials, serving as a legal basis for taking certain measures in the public arena. Such governmental authority can be obtained through the following three sources of authority, namely: ${ }^{19}$

a. Attribution, namely granting new, previously non-existing governmental authority by a law or regulation to perform governmental tasks to the full extent. In other words, authority by attribution is the creation of new authority, one that did not exist earlier and is specifically intended for the purpose of governance. Attribution is granted to the holder of authority to the full extent, including the authority to determine policy applicable internally as well as externally (generally appicable) which is subsequently articulated in the form laws and regulations. Consequently, the party which is granted authority by way of attribution also assumes full responsibility.

b. Delegation, namely the delegation of an existing authority originating from authority by attribution to a public official, however not to full extent. That is why delegation of authority is always preceded by authority by attribution. Delegated authority is not granted to the full extent, which means that it does not include authority to determine internally and externally, or generally applicable policy Responsibility is transferred to the party receiving the delegation of authority, up to the extent and scope of delegated authority.

c. Mandate, namely the party giving mandate to the party receiving such mandate to make state administration decisions or perform certain duties on behalf of the party giving mandate. Accordingly, authority remains in the hands of the party giving mandate and so does the relevant responsibility, none of which are transferred to the party receiving the mandate.

Government authority must be used in compliance with state administration law in order to ensure that no abuse of authority occurs. Such public authority consists of two extraordinary powers, namely as follows: ${ }^{20}$

a. Prealabel authority, namely the authority to make decisions without prior approval by any party whatsoever;

b. Ex Officio authority, namely authority due to position, whereby all decisions made by the official concerned are legally binding on the entire community and cannot be contested in the regular manner; rather, legal avenues provided for under oleh laws and regulations must be pursued.

In order to prevent abuse of authority by state administration officials in policy making, there is a need for certainty concerning delegation in making regulations, namely as follows:

a. The basic principles need to be set forth in law in such a manner that they are not

\footnotetext{
${ }^{18}$ Attribution is the granting of new authority to the government based on laws and regulations (legislative products) to implement governmental functions, to full extent. Delegation is delegation of an existing authority originating from attribution authority, to state administration officials, not to full extent. Mandate is assigning duty by the party granting mandate (mandans) to the party receiving such mandate, to undertake certain governmental acts on the former's behalf. (Safri Nugraha et.al, Hukum Administrasi Negara (State Administration Law), Center for Law and Good Governance Studies, 2007), p.35-36.

${ }^{19}$ Ibid., p. 41.

${ }^{20}$ Prayudi Atmosudirjo, Op.Cit., p . 88.
} 
subject to further elaboration or interpretation;

b. Delegation should be expressly provided for by setting forth the article related to matters being delegated, and providing for certain guidelines to state administration officials concerned in the relevant articles of the law.

c. Setting the requirement by law to conduct prior adequate study;

d. Providing under law for the volume and types of sanctions applicable for violations of the regulation concerned;

e. Delegation is conducted to state administration officials only;

f. The law provides for the establishmet of a body receiving reports, complaints or claims. ${ }^{21}$

\section{Authority in Mine Management prior to the Era of Regional Government Autonomy}

Prior to the commencement of the era of regional government autonomy in January 2000 marked by the coming into effect of Law Number 22 Year 1999, Law Number 5 Year 1974 concerning Regional Governance had been force. The management of mining had been provided for in Law Number 11 Year 1967 concerning the Basic Mining Provisions. Both of the said laws, namely Law Number 5 Year 1974 and Law Number 11 Year 1967, were in line with the distribution of regional autonomy authority and authority in mining management, with the attribution authority being vested in the Central Government. Both of the said laws were centralistic in nature and intent, basically granting attribution authority to the Central Government in the management of mining in accordance with the categories of excavated materials, whereby category a and b excavated materials were in principle under the Central Government's authority, while category c was given to the regional Government concerned. Authority for mining management was not based on the distribution of authority based on granting autonomy to the Regional Government. In other words, there was no attribution of authority to the Regional Government, except for certain matters based on the Minister's consideration and permit, as well as for category c excavated materials.

Law Number 11 Year 1967 concerning the Basic Mining Provisions provides that every entrepreneur intending to conduct mining activities must possess a Mining Concession (KP). ${ }^{22}$ The forms of $K P$ which can be potentially granted to the applying parties are as follows: ${ }^{23}$

a. Mining Concession (KP): granted to State Companies (Perusahaan Negara), Regional Companies (Perusahaan Daerah), Cooperatives, other legal entities of

\footnotetext{
${ }^{21}$ Prajudi Atmosudrijo, Hukum Administrasi Negara, (State Administration Law), ( Jakarta : Ghalia Indonesia, 1988), p. 104.

${ }^{22}$ Mining Concession (Kuasa Pertambangan - KP) is a form of license in the form of authority granted to an entity or individual to engage in the mining business. Holders of KP have the authority to implement one or several mining businesses determined in the KP concerned. The KP only grants the power to implement mining business and it does not grant ownership on mining products (hasil pertambangan) to the KP holder, because the owner of excavated materials contained in the depths of the earth is the Indonesian Nation (Article 7 of Law Number 11 Year 1967 concerning the Basic Mining Provisions, Supplement to State Gazette Number 2831).

${ }^{23}$ Article 6 up to Article 15 of Law Number 11 Year 1967 concerning the Basic Mining Provisions, Supplement to State Gazette Number 2831 jo. Government Regulation Number 32 Year 1969 concerning the Implementing Regulation of Law Number 11 Year 1967.
} 
individuals engaging in the mining business for excavated materials of category a and b (Article 15 Law Number 11 Year 1967);

b. Decision on Assignment (Assignment $K \boldsymbol{P}$ ): a form of $K P$ issued by the Minister to the Government Agenc concerned to engage in mining activities by conducting Research of excavated materials. (Article 6 of Law Number 11 Year 1967 jo Article 3 Government Regulation Number 32 Year 1969);

c. Decision on People's Mining License (SIPR): concession license for all categories ( $a, b$ and $c$ ) issued by the Minister to the local community from generation to generation, on a small scale and using rudimentary equipment (Article 11 Law Number 11 Year 1967 jo. Article 5 Government Regulation Number 32 Year 1969);

d. Regional Mining License (SIPD): issued by the Regional Government concerned to Companies/Legal Entities and Individuals for mining business involving category c excavated materials in their respective regions, granted by virtue of Government Regulation Number 37 Year 1986.

The above mentioned KP is issued based on the classification of excavated materials. ${ }^{24}$ In the context of classifying excavated materials which can be decentralized, there have been certain underlying considerations as to the classification of excavated materials into category a, b and c under Law Number 11 Year 1967. It is obvious that in line with the mandate of Article 33 paragraph (3) of the 1945 Constitution of the State of the Republic of Indonesia, excavated materials which cannot be decentralized are category a (strategic) and category b (vital), while category c can be decentralized to autonomous regions. Category a and $b$ excavated materials are considered to be strategic and vital to the State, with a potentially huge impact on the State, hence they need to be controlled by the Government. Notwithstanding the above, there are certain exemptions for authority in the management of category a and excavated materials based on the delegation of the Government's authority, both to the Regional Government as well as the business actors concerned. At the same time, category c excavated materials can be entirely submitted by way of attribution to the Regional Government concerned due to the locality nature of category c excavated materials. Such submission of excavated materials tersebut is based on Government Regulation Number 37 Year 1986 concerning the Submission of a Portion of Governmental Affairs in the Field of Mining to the Level I Regional Government.

Furthermore, provisions concerning authority in mining management under Law Number 11 Year 1967 set forth as follows: ${ }^{25}$

\footnotetext{
${ }^{24}$ Refer to Government Regulation Number 27 Year 1980 concerning the Classification of Excavated Materials, State Gazette Year 1980 Number 47, Supplement to State Gazette Number 3174, classifying excavated materials into three categories, namely : (a) category of strategic excavated materials (cat.a) : 1) solid bitumen, asphalt, 2) anthracite, coal, 3) uranium, radium,thorium and radioactive excavated materials, 4) nickel, cobalt,5) tin, (b) category of vital excavated materials (cat. b) : 1) iron, mangaan, molibdem, chrome, tungsten (wolfram), radium, titanium, 2) bauxite, copper, lead, zinc, 3) gold, platinum, silver, mercury, diamond, 4) yttrium, rhutenium, cerium and other scarce metals, 5) berillium, corundum, zircon, 6) kryolite, fluorspar, baryte 7) iodine, bromine (brom),chlorine, sulphur, (c) category of excavated materials not classified either as category a or category b (cat. c) : 1) nitrates, phosphates, rocksalt (garam batu), 2) asbestos, talc, mica, magnesite, 3) yarosite, leucite, alum, ocher, 4) precious stone, semi-precious stone, 5) quartz, kaolin, feldspar, gympsum, 6) pumice, trass, obsidium, pearlite, diatomaceous earth (tanah diatome), soil absorption (tanah serap), 7) marble, schist 8) limestone, dolomite, calcite, 9) granite, andesite, basalt, trachyte, clay and sand to the extent that it does not contain mineral of category a or category b.

${ }^{25}$ The Republic of Indonesia, Law Number 11 Year 1967 concerning Basic Mining Provisions, Supplement to State Gazette Number 2831, Article 4.
} 
a. control by the State and regulation of the mining business involving category a and $b$ excavated materials shall be implemented by the Minister.

b. control by the State control and regulation of the mining business involving category c excavated materials shall be implemented by the Level I Regional Government at the location of such excavated materials.

c. However, with the exception that with due observance of the interests of regional development in the region concerned in particular, and the State in general, the Minister can submit the regulation of mining business involving category $b$ excavated materials to the Level I Regional Government at the location of such excavated materials.

d. An opportunity is given to grant public contracts to Private Companies (investors) based on Public License from the Minister of Energy and Mineral Resources, which can be done if the Government Agency concerned is unable to implement it alone, the Minister can grant an approval to enter into a contract with another party.

e. Similarly for category c excavated materials, if they are located offshore and are under concession by Foreign Companies, it is implemented based on contract of work $(K K){ }^{26}$

f. Mining concession for category a excavated materials (strategic category) ${ }^{27}$ can only be implemented by a Government agency (especially in the general investigation and exploration phase, which is non-profit in nature) and State Companies (particularly in the stage of exploitation activities, which are starting to be profit oriented).

g. Furthermore, concession for category b excavated materials (vital category) can be implemented by any party, either by State Mining Company or Government Agency, Individuals or Private Legal Entities, insofar as they fulfill the requirements set forth in Article 12 paragraph (1) of Law Number 11 Year 1967.

h. Category c excavated materials, based on Article 4 paragraph (2) of Law Number 11 Year 1967 Jo. Government Regulation Number 37 Year 1986, have been officially delegated to the Regional Government, which is in practice known as Regional Mining License (SIPD).

i. Mining business conducted under Work of Contract based on Article 4 paragraph (1) Government Regulation Number 37 Year 1986 can be implemented in view of category a and b excavated materials in cooperation with the Government Agency concerned or a State Company in their capacity as the holder of $K P$, to the extent that they do not yet possess the ability to implement it by themselves.

j. Similarly, mining management business activities involving category c excavated materials can be implemented under Work of Contract to the extent that they are located offshore and are under concession by foreign parties.

Based on the provisions of Law Number 11 Year 1967 and the various implementing regulations thereof it becomes apparent that attribution authority in mining management, especially in view of category a and b excavated materials, is in the hands of the Government, and it is implemented by the Minister. However, in addition

\footnotetext{
${ }^{26}$ Government Regulation Number 37 Year 1986 concerning the Submission of A Portion of Governmental Affairs in the Mining Sector to the Level I Regional Government, State Gazette Number 53 Year 1986, Supplement to State Gazette Year 1986 Number 3510, Article 4.

${ }^{27}$ Law Number 11 Year 1967 concerning Basic Mining Provisions, Supplement to State Gazette Year 1967 Number 2831, Article 6.
} 
to the above, there is also delegation authority if the Minister considers that category $\mathrm{a}$ and $\mathrm{b}$ should be submitted to the Region concerned or to the Private Sector. Attribution authority in mining management submitted to the region specifically involves category c excavated materials.

\section{VI.Authority in Mining Management Following the Era of Regional Autonomy}

\section{A. Law Number 22 Year 1999}

The coming into effect of Law Number 22 Year 1999 as of January 1, 2000 officially marked the beginning of the era of regional government autonomy. In the era of regional governance fundamental changes took place, which can be considered as radical or drastic changes. Such changes involved, among other things, placing greater emphasis on decentralized rather than centralized governance. Furthermore, changes were also introduced in the distribution of governmental affairs, replacing the initially specific provisions setting out competences of the regional government with provisions formulated in a more general manner (referred to as open end arrangement) stating that the "Regional Government of Regency/Municipality shall administer various governmental affairs to the extent that they are not prohibited by Law or they are not subject to the (central) government's structural jurisdiction'. At the same time, the provincial government's affairs were expressly set forth, with such method being referred to as the ultra vires doctrine. Law Number 22 Year 1999 does not adopt regional government hierarchy between the Province and Regency/ Municipality. Initially, by virtue of Law Number 5 Year 1974, there was hierarchy between Level I and Level Regional Government, while with Law Number 22 Year 1999 coming into effect the hierarchy of regional government was no longer applied.

In the context of mining management, at that time Law Number 11 Year 1967 concerning Basic Mining Provisions was still in effect from the formal and juridical point of view up to the enactment of Law Number 4 Year 2009. However, in reality, the provisions of Law Number 11 Year 1967 are based on a spirit which is significantly different from and is not synchronous with Law Number 22 Year 1999, thus creating various issues in the course of its implementation. In principle, Law Number 11 Year 1967 adopts the centralistic principle, whereby the attribution of authority is in the hands of the Government, and only the delegation of authority is vested in the Regional Government. At the same time, Law Number 22 Year 1999 adopts the principle of regional autonomy to the broadest extent, enjoyed particularly by Regency and Municipality governments, namely by submitting various governmental affairs to the Regional Government with the exception of 6 (six) areas as provided for in Article 7 of Law Number 22 Year 1999, constituting the Central Government's authority. Accordingly, under Law Number 22 Year 1999 the authority for attribution is given to the Regional Government, to the Regency and Municipality Government in particular. The above mentioned asynchrony persisted for a rather long period of time, namely up to the enactment of Law Number 4 Year 2009 concerning Mineral and Coal Mining which came into force in January 2010.

Law Number 22 Year 1999 provides authority in the management of mining affairs 
to the autonomous regions, namely to the Province, Regency or Municipality in accordance with their respective authorities. In Article 10 of Law Number 22 Year $1999{ }^{28}$ it is stated that the regions are granted authority in managing national resources available in their areas and are responsible for maintaining and preserving the environment in accordance with laws and regulations. This led to the interpretation that the management and regulation of mining affairs was submitted to the autonomous regions. The implementing regulation of Law Number 22 Year 1999, namely Government Regulation Number 25 Year 2000, specifically sets forth the distribution of authority between the Central Government and the Provincial, Regency/Municipality Governments as Autonomous Regions. ${ }^{29}$

As a consequence of the change of model and the adoption of the open end arrangement in submitting governmental affairs to regencies and municipalities, there was an increase in the affairs handled by regencies and municipalities. In addition to that, there was also a change in the types of governmental affairs handled by regencies and municipalities which had initially not included mining affairs. In Article 11 of Law Number 22 Year 1999 it is stated that some of the governmental affairs to be submitted to the regency/municipality include the following: public works, health, education and culture, agriculture, industry and trade, capital investment, environment, defense, cooperatives and manpower. ${ }^{30}$ It does not include affairs in the mining sector, whereby mining affairs are not within the autonomous regions' mandatory responsibilities; rather than that, they are optional affairs. ${ }^{31}$ However, quite unfortunately, the mining sector itself introduced a policy which was in fact contradictory, namely by submitting authority in the management of mining to the Regional Government, by adopting Government Regulation Number 75 Year 2001. From that point on, mining affairs were considered as the full authority of the Regional Government, specifically the Regency and Municipality Government. It is quite evident from the above that the attribution authority in mining management is based on a Government Regulation, rather than a Law. Attribution authority should

${ }^{28}$ The regions have the authority to manage national resources available in their respective areas and are responsible for preserving the environment in accordance with laws and regulations. (Article 10 paragraph 1 of Law Number 22 Year 1999 concerning Regional Governance).

${ }^{29}$ Authority in the mining and energy sector constituting the authority of the Province include the following, among other things (a) stipulation of policy on intensification, diversification, conservation and energy pricing, (b) stipulation of policy concerning national/regional electricity and natural gas transmission network, (c) stipulation of standards for monitoring and investigating geological natural disaster, (d) stipulation of standards for general investigation and standards for the management of mineral resources and energy as well as underground water, (e) stipulation of the criteria for business working area including the distribution of electricity and mining, (f) stipulation of supply and basic rates for electricity, fuel, gas and natural gas domestically, (g) providing for basic geological surveys and small scale underground water surveys, or equivalent to 1.250 .000 , preparation of thematic maps and inventory of mineral and energy resources as well as geological disaster mitigation, $(\mathrm{h})$ regulating electric power generating, transmission and distribution in the national grid and the use of nuclear power plants as well as providing for the use of radio active mining materials, (i) issuing core business license for oil and gas starting from the exploration stage up to the transportation of natural oil and gas through pipelines across provinces, (j) issuing core business licence for electric power including power plants across provinces, transmission and distribution, (k) issuing non-core business license including depots across provinces and oil and gas transmission pipelines. (Government Regulation Number 25 Year 2000 concerning The Authority of the Government and the Regional Government as Autonomous Regions, State Gazette of the Republic Indonesia Year 2000 Number 54, Article 1).

${ }^{30}$ The Republic of Indonesia, Law Number 22 Year 1999 concerning Regional Governance, Article 11.

${ }^{31}$ Regions have the authority to manage national resources available in their respective areas and are responsible for preserving the environment in accordance with laws and regulations. Ibid., Article 10. 
be submitted by virtue of a Law, whereas a Government Regulations may only grant delegation authority in implementation of the relevant Law.

In 2004 Law Number 22 Year 1999 was amended, which was eventually replaced with Law Number 32 Year 2004 concerning Regional Governance. Mining affairs were also optional rather than mandatory affairs ${ }^{32}$ required of the Province and/or Regency/ Municipality governments. ${ }^{33}$ Mandatory affairs which became part of the Province's disceriotn were affairs at the scale of the Province ${ }^{34}$ Affairs forming part of the regency/municipality's authority were affairs at the scale of regency/municipality. ${ }^{35}$

The implementing regulation of Law Number 32 Year 2004, namely Government Regulation Number 38 Year 2007 concerning the Distribution of Affairs between the Central, Provincial Government, and the Regency/Municipality Government specifically sets forth several authoritys constitution the authority of the Central, Provincial and Regency/Municipality Governments respectively. ${ }^{36}$ Article 2 of

${ }^{32}$ Mandatory affairs are those that are fundamentally related to the basic rights and services to citizens, including among other things: a) the protection of constitution rights, b) the protectino of national interests, the people's welfare, peace and public order in the context of maintaining the integrity of the Unitary State of the Republic of Indonesia, c) fulfillment of the national commitment related to international agreements and conventions. Elucidation on Article 11 of Law Number 32 Year 2004 concerning Regional Governance, State Gazette of the Republic of Indonesia Year 2004 Number 125, Supplement to State Gazette Number 4437.

${ }^{33}$ Optional affairs include concrete affairs which can potentially promote people's welfare in accordance with the conditions, unique characteristics, and primary potentials of the regions concerned. Ibid., Article 14 paragraph (2).

${ }^{34}$ Mandatory affairs constitution the authority of the Province: a) development planning and control, b) spatial planning, utilization and supervisions, c) maintaining public order and peace in the community, d) providing public infrastructure and facilities, e) handling the health sector, f) organizing education and allocation of potential human resources, g) management of social issues across regencies, h) services in the field of manpower, i) facilities for the development of cooperatives, small and medium enterprises, including across regencies, j) environmental control, k) defense services including across regencies, l) population and vital records services, $\mathrm{m}$ ) public governmental administration services, $\mathrm{n}$ ) capital investment adminitration services including across regencies, o) organizing other basic services which cannot be implemented yet by the regency or city concerned, p) other mandatory affairs mandated by laws and regulations. Ibid., Article 13 paragraph (1).

${ }^{35}$ Mandatory affairs constituting the authority of regency/municipality: a) development planning and control, b) spatial planning, utilization and supervision, c) administering public interest, d) providing public infrastructure and facilities, e) handling the health sector,f) organizing education, g) dealing with social issues, h) services in the field of manpower, i) facilities for the development of cooperatives, small and medium enterprises, $\mathrm{j}$ ) environmental control, $\mathrm{k}$ ) defense services, l) population and vital records services, $\mathrm{m}$ ) public governmental administration services, n) capital investment administraiton services, o) organizing other basic serivces mandated by laws and regulations. Ibid., Article 14 paragraph (1).

${ }^{36}$ Governmental affairs consist of governmental affairs which are entirely the authority of the Government as well as governmental affairs shared across the various governmental levels and/or organizational structures. Governmental affairs constituting the Government's authority include the following: foreign politics, defense, security, justice, monetary, and national finances as well as religious affairs. Governmental affairs shared across various levels of government include the following: education, health, public works, housing, spatial planning, development planning, communications, the environment, defense, population and vital records, women's empowerment and child protection, family planning, social affairs, manpower, cooperatives, capital investment, culture and tourism, youth affairs, domestic politics, regional autonomy, general governance, regional finances, regional apparatus, employment matters, intelligence, community empowerment, statistics, archives, libraries, communication and information, agriculture, forestry, energy and mineral resources, maritime affairs and fisheries. (Government Regulation Number 38 Year 2007 concerning Distribution of Governmental Affairs Between the Government, the Regional Government of Province and the Regional Government of Regency/Municipality. State Gazette of the Republic of Indonesia Year 2007 Number 82. Article 2). 
Government Regulation Number 38 Year 2007 states that governmental affairs consist of those that are fully the Government's authority and governmental affairs shared among the various governance levels and/or organizational structures. Consequently, there are no affairs which are the absolute authority of the autonomous regions. The same is applicable to mining affairs which are governmental affairs jointly distributed among governmental levels.

\section{B. Government Regulation Number 75 Year 2001}

As an impact of the era of regional autonomy starting with the adoption of Law Number 22 Year 1999 concerning "Regional Governance" as amended with Law Number 32 Year 2004, brought fundamental changes in the authority related to the management of mining and the forms of concession licenses in the mining sector in Indonesia. Parallel to such changes various issues emerged in practice, among other things legal uncertainty in the implemelntation of variouslawas and regulations, as well as multiple interpretations of authority in licensing, thus creating disharmony across various related sectors. In the context of anticipating such changes, the Government issued Government Regulation Number 75 Year 2001 concerning the "Submission of Authority in Mining to the Regional Government", granting full authority in the management of mining by attribution to the Regency and Municipality Regional Government pengelolaan pertambangan secara atributif kepada Pemerintah Daerah Kabupaten in terms of governmental affairs, with the exception of 6 (six) areas constituting the Central Government's affairs.

With the applicability of Government Regulation Number 75 Year 2001, all mineral and coal mining affairs were submitted to the Regional Governments in accordance with their respective authoritys, which was adapted to the submission of regional autonomy to the regional governments. However, the above mentioned Government Regulation continues to recognize the classification of excavated materials as set forth in Law Number 11 Year 1967 which was still legally effective and binding. Article 1 of Government Regulation Number 75 Year 2001 states that every mining business involving category a and b excavated materials can be implemented if it has already obtained a Mining Concession (KP) issued by the Regent, Mayor and Governor in accordance with their respective authorities. ${ }^{37}$ Even though it still recognizes the classification of excavated materials, Government Regulation Number 75 Year 2001 mandates that authority by attribution for licensing is determined depending on the location at which the mining activities concerned are taking place, whereby it can constitute the authority of the Regent, Mayor, Governor or the Minister in accordance with their authority respectively. It becomes a primary issue in view of the fact that authority by attribution must be granted based on Law. At the same time, granting authority based on Government Regulation should only be done for granting authority by delegation, in line with the nature of Government Regulation itself which is issued as a form of delegation by Law.

\footnotetext{
${ }^{37} \mathrm{KP}$ can be granted by: (a) Regent/Mayor if the WKP is located within the territory ofthe Regency/ Municipality concerned and/or in sea territory up to 4 nautical miles; (b) Governor if the KP Area s located in the territory of several Regencies/Municipalities and there is no cooperation among such Regencies/ Municipalities and/or betwee the Regencies/Municipalities concerne and the Province and/or in sea territory lcoated between 4 nautical miles to 12 nautical miles; (c) Minister if the KP Area is located in several Province territories and there is no cooperation among such Provincies and/or in sea territory located beyond 12 nautical miles.
} 
The introduction of Government Regulation Number 75 Year 2001 weakened the implementation of Law Number 11 Year 1967 in the management of mining activities. The asynchrony between the said two regulations created dualism in the authority of the Central Government and the autonomous regions in view of licensing. In principle, Law Number 11 Year 1967 grants mining licensing authority to the Central Government as set forth in Article 4, while Government Regulation Number 75 Year 2001 based on Article 1 paragraph (2), grants mining licensing authority based on the submission of autonomy to the regions, thus depending on the location of the mining activities concerned licenses can be issued by the Regent, Mayor, Governor or Minister in accordance with the their authority respectively. It becomes evident that both the Law and the Government Regulation grant authority by attribution to the Regional Government. It is at this point that a juridical issue arises related to the legality of the Regional Government in mining management.

Consequently, the regions started issuing their own Regional Regulations concerning the management of mining to suit their needs, without using a basic reference. The mandate of Law Number 11 Year 1967 which is based on centralistic concept is no longer used as reference in regulation at the Regional Government level. The concept of submission and delegation of authority as provided for in Law Number 11 Year 1967 is no longer referred to. The concept of submission of authority in mining management refers to Law Number 22 Year 1999 as replaced with Law Number 32 Year 2004, subsequently facilitated by Government Regulation Number 75 Year 2001 which submits authority in mining management to the Minister/Governor/Regent/ Mayor in accordance with their authority respectively, based on the location at which mining activities are conducted. This has led to the proliferation of illegal mining and mining without license (pertambangan tanpa izin or PETI) under the cover of people's mining.

Such situation involving authority in mining management without reference to the Law continued for a rather long period of time, namely since 2001 up to the enactment of Law Number 4 Year 2009. In other words, for over 10 years, authority in the management of mining in Indonesia was exercised without a legal basis in the Mining Law. It is highly ironical, indeed, as substantial losses were certainly incurred by the state finances due to the legal uncertainty prevailing in the management of mining in Indonesia.

\section{Law Number 4 Year 2009}

Authority for the management of mineral and coal mining is in the hands of the Government, Provincial and Regency/Municipality Government in accordance with their authority respectively. ${ }^{38}$ Authority granted in this case is authority by

\footnotetext{
${ }^{38}$ The Government's authority in the management of mineral and coal mining includes the following, among other things: stipulating national policy, making laws and regulations, stipulating national standards, guidelines and criteria, stipulating the licensing system in the mineral and coal mining sector, stipulating areas, issuing IUP, guidance, community dispute settlement across provinces and/or sea territory beyond 12 nautical miles from the coastline, issuing Exploration IUPK and Production Operation IUPK, Stipulating Marketing Production Policy, exploitation and conservation, stipulating common policy, partnership and community empowerment, formulating and stip9ulating non-tax State revenues from mineral and coal mining.

The Regional Government's authority includes the following, among other things: making laws and regulations, issuing $I U P$, guidance, community dispute settlement and supervision of mining business across Regencies/ municipalities and/or sea territory 4 miles up to and including 12 nautical miles, issuing IUP, guidance, com-
} 
attribution in licensing, hence the authority of the Central Government as intended in Law Number 11 Year 1967 is no longer applied. The Central Government's role is limited to determining the Mining Area, whereas licensing is subsequently submitted to the Regional Government concerned. Article 9 of Law Number 4 Year 2009 states that Mining Area is part of national spacial planning stipulated by the Government (Central) following coordination with the regional government concerned and consultation with the House of Representatives (DPR). Mining Area consists of the following:

(a) Mining Business Area stipulated by the Government following coordination with the Regional Government concerned and submitted in writing to the House of Representatives (DPR). A Mining Business Area consists of one or a number of Mining Business License Areas;

(b) People's Mining Area (Wilayah Pertambangan Rakyat) stipulated by the Regent/Mayor concerned following consultation with the Regional House of Representatives (DPRD);

(c) State Allocation Area (Wilayah Pencadangan Negara) stipulated by the Government for national strategic purposes allocated for certain commodities and conservation areas in the context of maintaining balance of the ecosystem and the environment.

Up to the present time (May 2014) not all of the Mining Business Areas which form part of spatial planning have been stipulated by the Government, as the approval of the DPR is yet to be obtained. Accordingly, the Regional Government, vested with the authority to issue Mining Business Licenses, is unable to exercise such authority. ${ }^{39}$ All of these factors trigger the issuance of licenses which deviate from prevailing regulations.

The form "Agreement" of "Contract" with the Government adopted so far based on Law Number 11 Year 1967, is no longer recognized. This raises an issue which has been at the center of ongoing debate among various related parties. A central issue related to Law Number 4 Year 2009 is the adjustment of $K P$ and Contract form to IUP. Adjustment of contract form to IUP in particular, as these two forms of mining business involve different regimes. This is an unresolved issue which is yet to be tackled by the Government.

The types of mining business are classified into the following categories: (a) Mineral Mining, including: (a.1) radioactive mineral mining, (a.2) metal mineral mining, (a.3) non-metal mineral mining, (a.4) rock mining and (b) Coal Mining. Law Number 4 Year

munity dispute settlement and supervision of mining business production operation conducting activities within the IUP Issued, guidance, community dispute settlement and supervision of mining business conducted across Regencies/Municipalities and/or sea territory of 4 nautical miles up to and including 12 nautical miles, issuing IUP, buidance, community dispute settlement and supervision of mining business which has a direct impact across Regencies/Municipalities and/or sea territory of 4 nautical miles up to and including 12 nautical miles.

The authority of the Regency/Municipality Government consists of the following, among other things: making laws and regulations, issuing IUP, IPR, guidance, community dispute settlement and supervision of mining business within the territory of the Regency/Municipality concerned and/or sea territory up to and including 4 nautical miles, issuing IUP, IPR, guidance, community dispute settlement and supervision of mining business production operation with activities conducted in the territory of Regency/Municipality and/or sea territory up to and including 4 nautical miles. (Refer to Law Number 4 Year 2009 concerning Mineral and Coal Mining, Article 6).

${ }^{39}$ Statement by resource persons (head of the Data and Information Division) at the Mining Service Office Bangka Belitung Islands and the Head of Mining Service Office in West Bangka Regency, on Monday, March 14, 2011. 
2009 concerning Mineral and Coal Mining adopts several forms of licensing, namely as follows:

(1) Mining Business Permit (IUP) is a business license for conducting mining issued by the Minister, Governor, Regent in accordance with their authority respectively (Article 1 sub-article 7), which covers the following:

(a) Exploration IUP is a business license issued for engaging in activities in the stage of general investigation, exploration and feasibility study (Article 1 sub-article 8);

(b) Production Operation IUP is a business license issued following the completion of the Exploration IUP to implement the production operation stage (Article 1 sub-article 9). The Production Operation IUP consists of construction, mining, processing and refinery activities, as well as transport and sale.

(2) People's Mining License (IPR) is a license to conduct mining within people's mining area with a limited area and investment, issued by the Minister, Governor, Regent in accordance with their authority respectively (Article 1 sub-article 10). The Regent/Mayor issues IPR mainly to local residents, both to individuals for a maximum of 1 hectares, as well as to community groups for a maximum of 5 hectares and/or cooperatives for a maximum of 10 hectares. It can be delegated to the district head (camat) in compliance with prevailing laws and regulations.

(3) Special Mining Business License (IUPK) is a license to conduct mining business activities in a special mining business license area (WIUPK: Article 1 sub-article 11). Special mining business license area is an area allocated to the holders of IUPK (Article 1 sub-article 35).

IUPK consists of two stages, namely as follows:

(a) IUPK in the Exploration stage is a business license for conducting activities in the stage of general investigation, exploration and feasibility study in the special mining business license area (Article 1 sub-article 12).

(b) IUPK in the Production Operation stage is a business license issued upon the completion of the Exploration IUPK for the purpose implementing activities in the production operation stage in the special mining business license area (Article 1 sub-article 13).

\section{Conclusion}

Prior to the adoption of Law Number 22 Year 1999, the concept of mining management was based on Law Number 11 Year 1967, in accordance with the mandate articulated in Article 33 paragraph (3) of the 1945 Constitution, which was basically centralistic in nature, namely authority by attribution in mining management (particularly category a and b excavated materials) was vested in the Central Government.

Upon Law Number 22 Year 1999 coming into effect, marking the commencement of the era of regional autonomy, the concept of mining management also started to undergo changes, namely by granting authority by attribution to the regional government, validated by the issuance of Government Regulation Number 75 Year 2001.

The manifestation of the concept of control by the state as intended in Article 33 
paragraph (3) of the 1945 Constitution of the State of the Republic of Indonesia needs to be aligned in Law Number 4 Year 2009 concerning "Mineral and Coal Mining", bearing in mind that the concept of control by the State which refers to the "character state" implying that authority in management should be vested in the Central Government, has become degraded by granting management authority to the Minister, Governor, Regent/Mayor in accordance with their authority respectively;

According to the public interest theory of Anthony I Ogus, the form of Mining Business License as adopted in Law Number 4 Year 2009, from the substantive point of view the IUP belongs to the category of objects of Public Ownership.

\section{Bibilography}

Books:

Budiman, Arif. Kekuasaan dan Penguasaan Sumber Daya Alam, Studi Kasus Penambangan Timah di Bangka. (Power and Control of Natural Resources, Case Study on Tin Mining in Bangka.) Jakarta : Indonesia Center for Sustainable Development, 2007.

Carol Harlow and Richard Rowling. Law and Administration. London : Butterwoths, 1997.

Caiden, Gerald. The Dynamics of Public Administration in Theory and Practice. New York : Holt, Reinhart and Winston Inc., 1971.

Creswell, John. Research Design, Qualitative and Quantitative Approaches. Diterjemahkan oleh Angkatan III - IV, KIK UI. Jakarta : KIK Press, 2002.

Hadjon, Philipus et al., Pengantar Hukum Administrasi Indonesia (Introduction to Indonesian Administrative Law), print 7. Jogjakarta : Gadjah Mada University Press, 2001.

Harlow, Carol and Richard Rawlings. Law and Administration. London : Butter Worth, 1997.

Hayati, Tri, Perizinan Pertambangan di Era Reformasi Pemerintahan Daerah, Studi tentang Perizinan Pertambangan Timah di Pulau Bangka (Mining Licensing in the Era of Regional Governance Reform), print 1. Jakarta : Badan penerbit Fakultas Hukum Universitas Indonesia (Faculty of Law, Universitas Indonesia, Press), 2012.

Hoessein, Bhenyamin. "Pelaksanaan Pengusahaan Pertambangan di Era Otonomi Daerah" ("The Implementation of Mining Business in the Era of Regional Autonomy). Jakarta : Forum Diskusi Departemen Pertambangan dan Energi (Discussion Forum of the Department of Mining and Energy), 2000.

. Berbagai Faktor Yang Mempengaruhi Besarnya Otonomi Daerah Tingkat II. (Influencing Factors in the Expansion of Level II Regional Autonomy). Dissertation at the Post-Graduate Studies Program, FISIP UI, 1993.

Perubahan Model, Pola dan Bentuk Pemerintahan Daerah : Dari Era Orde Baru ke Era Reformasi. (Changes in the Model, Patterna and Form of Regional Governance) Jakarta : Departemen Ilmu Administrasi (Administration Science Department), FISIP UI, 2009.

H.S, Salim. Hukum Pertambangan di Indonesia. (Mining Law in Indonesia) Jakarta : PT Raja Grafindo Persada, 2005.

Indonesian Mining Association. Dedikasi Industri Pertambangan Bagi Pertumbuhan Ekonomi Indonesia. (Dedication of the Mining Industry to the Indonesian Economy) Jakarta : March 2006. 
I. Ogus Anthony, Regulation : Legal Form and Economic Theory. Portland, Oregon : Hart Publishing Ltd, 2004.

Saleng, Abrar, Hukum Pertambangan, (Mining Law), second ed. Jogjakarta : UII Press, 2007.

Safri Nugraha et al., Hukum Administrasi Negara, (State Administration Law) second edition, Jakarta : Center For Law and Good Governance Studies, FHUI, 2007;

Safri Nugraha et al., Hukum Administrasi Negara, (State Administration Law) Jakarta : Badan penerbit Fakultas Hukum Universitas Indonesia, (Faculty of Law, Universitas Indonesia Press), 2005.

Peter Leyland and Terry Woods, Administrative Law, third edition, (London : Blackstone Press Limited, 1999.

Laws and Regulations :

Indonesia, Undang-Undang Nomor 1 Tahun 1967 tentang Penanaman Modal Asing. (Law Number 1 Year 1967 concerning Foreign Capital Investment). State Gazette of the Republic of Indonesia Year 1967 Number 1. Supplement to State Gazette Number 2818.

Undang-Undang Nomor 11 Tahun 1967 tentang Ketentuan PokokPokok Pertambangan. (Law Number 11 Year 1967 concerning Basic Mining Provisions). State Gazette of the Republic of Indonesia Year 1967 Number 22. Supplement to State Gazette Number 2831.

Undang-Undang Nomor 22 Tahun 1999 tentang Pemerintahan Daerah. (Law Number 22 Year 1999 concerning Regional Governance). State Gazette of the Republic of Indonesia Year 1999 Number 60. Supplement to State Gazette Number 3839.

- Undang-Undang Nomor 32 Tahun 2004 tentang Pemerintahan Daerah. (Law Number 32 Year 2004 concerning Regional Governance). State Gazette of the State of the Republic of Indonesia Year 2004 Number 125. Supplement to State Gazette Number 4437.

--- Undang-Undang Nomor 4 Tahun 2009 tentang Mineral dan Batubara. (Law Number 4 Year 2009 concerning Minerals and Coal). State Gazette of the Republic of Indonesia Year 2009 Number 4959. Supplement to State Gazette Number 2009.

Peraturan Pemerintah Nomor 32 Tahun 1969 tentang Peraturan Pelaksanaan Undang-Undang Pokok Pertambangan. (Government Regulation Number 32 Year 1969 concerning Provisions for the Implementation of the Law Concerning the Basic Mining Provisions). State Gazette of the Republic of Indonesia Year 1969 Number 60. Supplement to State Gazette Number 2916.

Peraturan Pemerintah Nomor 27 Tahun 1980 tentang Penggolongan Bahan-bahan Galian. (Government Regulation Number 27 Year 1980 concerning the Classification of Excavated Materials). State Gazette of the Republic of Indonesia Year 1980 Number 47. Supplement to State Gazette Number 3174.

- Peraturan Pemerintah Nomor 37 Tahun 1986 tentang Penyerahan Sebagian Urusan Pemerintahan di bidang Pertambangan Kepada Pemerintah Daerah Tingkat I. (Government Regulation Number 37 Year 1986 concerning the Submission of a Portion of Governmental Affairs in the Mining Sector to the Level I Regional Government). State Gazette of the Republic of Indonesia Year 1986 Number 53. Supplement to State Gazette Number 3510.

Peraturan Pemerintah Nomor 25 Tahun 2000 tentang Kewenangan Pemerintahan dan Kewenangan Provinsi sebagai Daerah Otonom. (Government Regulation Number 25 Year 2000 concerning the Authority of the Government 
and the Authority of the Province as Autonomous Region). State Gazette of the Republic of Indonesia Year 2000 Number 54. Supplement to State Gazette Number 3952.

Peraturan Pemerintah Nomor 75 Tahun 2001 tentang Perubahan Kedua Peraturan Pemerintah Nomor 32 Tahun 1969 tentang Pelaksanaan Undang-Undang Nomor 11 Tahun 1967 tentang Ketentuan-Ketentuan Pokok Pertambangan. (Government Regulation Number 75 Year 2001 concerning the Second Amendment of Government Regulation Number 32 Year 1969 concerning the Implementation of Law Numb er 11 Year 1967 concerning Basic Mining Provisions.) State Gazette of the Republic of Indonesia Year 2001 Number 141. Supplement to State Gazette Number 4154.

Peraturan Pemerintah Nomor 38 Tahun 2007 tentang Pembagian Kewenangan antara Pemerintah Pusat dan Daerah. (Government Regulation Number 38 Year 2007 concerning the Distribution of Authority between the Central Government and the Regional Government). State Gazette of the Republic of Indonesia Year 2007 Number 82. Supplement to State Gazette Number 4729. 